\title{
CPUE comparison of traditional crayfish fyke net rigged with knotted net and alternatively knotless net
}

\section{Düğümlü ağdan donanmış geleneksel kerevit pinteri ile alternatif olarak düğümsüz ağdan donanmış pinterlerin CPUE karşılaştırması}

\author{
Mehmet Cilbiz $^{1 *}$ - Rahmi Uysal2 \\ ${ }^{1}$ Fisheries Research Institute, 32500 Eğirdir, Isparta-Turkey \\ 2 Fisheries Research Institute, 32500 Eğirdir, Isparta-Turkey \\ ${ }^{3}$ Fisheries Research Institute, 32500 Eğirdir, Isparta-Turkey \\ ${ }^{4}$ Fisheries Research Institute, 32500 Eğirdir, Isparta-Turkey \\ ${ }^{5}$ Fisheries Research Institute, 32500 Eğirdir, Isparta-Turkey \\ ${ }^{6}$ Fisheries Research Institute, 32500 Eğirdir, Isparta-Turkey \\ *Corresponding author: mehmetcilbiz@gmail.com
}

- Abdulkadir Yağcı ${ }^{3}$

\author{
S. Oğuz Korkut ${ }^{4} \bullet$ Kadir Çapkın ${ }^{5}$ \\ - Mehmet Cesur 6 \\ (iD) https://orcid.org/0000-0002-7686-7570 \\ (iD https://orcid.org/0000-0002-7342-9380 \\ (iD) https://orcid.org/0000-0002-7897-1734 \\ (i) https://orcid.org/0000-0002-6576-3557 \\ (iD https://orcid.org/0000-0002-6822-6896 \\ (D) https://orcid.org/0000-0002-7482-6353
}

Received date: 13.03 .2020

Accepted date: 26.11 .2020

Cilbiz, M., Uysal, R., Yağcı, A., Korkut, S.O., Çapkın, K. \& Cesur, M. (2021). CPUE comparison of traditional crayfish fyke net rigged with knotted net and alternatively knotless net. Ege Journal of Fisheries and Aquatic Sciences, 38(1), 79-86. DOI: 10.12714/egejfas.38.1.09

Abstract: In this study, it is aimed to compare the yield and strength of the crayfish fyke rigged with knotless net with $210 \mathrm{~d} / 12$ rope thickness with those of the traditional net material rigged with 210d/6 knotted net which is widely used in Turkey in fishing crayfish (Pontastacus leptodactylus, Eschscholtz, 1823). The study was carried out on a monthly basis between June 2017 and May 2018. In the study, a total of 300 fyke nets, equipped with 150 classical and 150 alternative nets, were used. The caught crayfishes were measured and weighted according to the fyke net they were caught in. A total of 3509 crayfish were caught, 1465 of which were caught with alternative fyke net and 2044 with traditional fyke net. Average CPUE value ranged from 10.93 (g/fyke net/day) to 281.14 (g/fyke net/day) for per fishing operation. Average CPUE value of the traditional gear was found to be 98.34 (g/fyke net/day), while that of the alternative gear was determined as 79.46 (g/fyke net/day), and no statistically significant difference was found between average CPUE values ( $p>0.05$ ). Average strength value of the traditional fyke net was determined as $( \pm S E) 10.43 \pm 0.27 \mathrm{~kg}$, while that value in $210 \mathrm{~d} / 12 \mathrm{knotless}$ net was identified as $14.50 \pm 0.91 \mathrm{~kg}(\mathrm{p}<0.05)$. Although it has high strength, since the CPUE value of the alternative fyke net is lower by $19.20 \%$ compared to the traditional gear, it is believed that its use in crayfish fishing will not be profitable.

Keywords: Small scale fisheries, catch-per-unit-effort, Hirfanlı Dam Lake, fyke net

Öz: Bu çalışmada, Türkiye'de kerevit (Pontastacus leptodactylus, Eschscholtz, 1823) avcliğında kullanılmakta olan 210d/6 numara düğümlü ağdan donanmış geleneksel ağ materyali yerine, $210 \mathrm{~d} / 12$ numara ip kalınlığındaki düğümsüz ağdan donanmış olan kerevit pinterinin verim ve mukavemetinin karşılaştıııması amaçlanmış̦tı. Çalışma Haziran 2017 ile Mayıs 2018 döneminde aylık olarak yürütülmüştür. Çalışmada 150 adet klasik, 150 adette alternatif ağdan donanmış olan toplam 300 adet pinter kullanılmıştır. Avlanan kerevitler, avlandıkları pinterlere göre ayrılmış ağırlık ve boy ölçümleri yapılmışır. $1465^{\prime \prime}$ alternatif pinter, 2044'ü de geleneksel pinter ile avlanmış toplam 3509 adet kerevit yakalanmışır. Operasyon başına ortalama CPUE değeri 10,93 (g/pinter/gün) ile 281,14 (g/pinter/gün) arasında değişim göstermiştir. Geleneksel takımın ortalama CPUE değeri 98,34 (g/pinter/gün) bulunmuş iken alternatif takımınki ise 79,46 (g/pinter/gün) olarak bulunmuş olup; ortalama CPUE değerleri arasında istatistiki farkılıı bulunmamıștı ( $p>0.05$ ). Geleneksel pinter ağının kopma direnci değeri ortalama $( \pm S E)$ 10,43 $\pm 0,27 \mathrm{~kg} ; 210 \mathrm{~d} / 12$ düğümsüz ağın ki ise 14,50 $\pm 0,91 \mathrm{~kg}$ olarak belirlenmiştir $(p<0.05)$. Her ne kadar yüksek mukavemete sahip olsa da alternatif pinterin CPUE'unun geleneksel takıma göre $\% 19,20$ oranında düşük olması nedeniyle, kerevit avcılığında kullanımının daha verimsiz olacağı düşünülmektedir.

Anahtar kelimeler: Küçük ölçekli balıkçılık, birim çabada av, Hirfanlı Baraj Gölü, pinter

\section{INTRODUCTION}

Hunting and fishing are among the oldest professions in the world and their origins date back to the history of humanity (Tokaç, 2011). Fishing, in the simplest terms, is the catching of aquatic wildlife according to Pauly et al. (2002). Fishing based on collecting at the beginning was begun to be performed with different tools in the following years. The fishing process, which started with simple harpoons made of bone (Tokaç, 2011), has transformed today into industrial fishing vessels supported by advanced technology. Currently, many different fishing gears with different features are used in both commercial and amateur fishing. While until the 1980s, the most important criterion in a good fishing gear was high fishing efficiency, today, research on the development of ecological gears that have high selectivity and cause the least harm to the environment have become more prominent due to the decreasing fish stocks.

One of the most important criteria that affects the development process of fishing gear is the biological features of the target species. Drift nets or pelagic loglines are not 
expected to yield good results in fishing the aquaculture living at the bottom; therefore, a fishing gear should be designed for fishing the creatures living at the bottom. Different types of traps (USA, Australia, etc.) and fyke nets (Turkey, China, Iran, Armenia, Egypt, etc.) were developed to serve this purpose (Fujimoto et al., 2017; Ulikowski et al., 2017; Green et al., 2018), specifically for crayfish. The main strategy here is (I)turning the sheltering needs of crayfish into an advantage and luring them into traps in the form of a shelter, (II) guiding them to the trap with the help of the leader net and (III) trapping them by using their feeding instincts through traps with added feed.

Fyke nets are used in crayfish fishing in Turkey. In general framework, crayfish fyke net is identified as a small eel fyke net which was explained by Tosunoğlu et al. (2017) as Söke type double fyke net. The fact that it opens and closes like an accordion makes it very easy to carry and stack. This situation provides a great advantage for Turkish inland waters fishermen who have fishing boats with low hull lengths $(\sim 7-9 \mathrm{~m})$. They are lightweight, so they can be removed from the water with hand power without the need for engine power for harvesting.

In addition to the developing technology, changing biotic and abiotic factors can make it necessary to develop or change existing fishing gear as well. For example, balloon fish, which are an invasive species in the Mediterranean Sea, cause serious damage to fishing gear besides the ecological damage they create. Fishermen, as a response, have started to search for reliable fishing methods. Amateur fishermen have started to use steel shackle instead of the traditional polyethylene $(P E)$ based monofilament fishing line shackle. Another example can be given from inland fisheries. In these environments, which have a higher biological load compared to sea water, the rapid contamination of gillnets produced from multifilament material causes very serious reductions in catch productivity. Therefore, fishermen prefer to use nets made of monofilament material, which is more resistant to contamination. Ayaz et al. (2006) reported that accumulation of detritus and biofouling material declined of total fishing area of gillnet. In this context, there are some problems in crayfish fishing in Turkey arising from freshwater crab (Potamon potamios, Olivier 1804). This species, shows a widespread distribution in Turkey (Geldiay and Kocataş, 1977; Gülle et al., 2007), cuts the fyke net rope with its powerful claws and causes a decrease in catch yield, which consequently leads to economic losses. This situation forces fishermen who are engaged in crayfish fishing to search for materials that may have higher resistance to freshwater crab. However, the most important feature of the new material to be tested is that the catch efficiency must be better or at least the same as that of the previously used gear. Otherwise, the use of the gear should not be expected to become widespread.

In the studies done on fyke net fishing to date, such issues as determination of selectivity (Bevacqua et al., 2009; Bolat and Uçgun, 2019; Kraft and Johnson, 1992), developing selectivity (Cilbiz, 2019), determination of fishing composition (Fische et al., 2010; Hardie et al., 2005; Tsai et al., 2015), the effect of feed usage on catch yield (Balık et al., 2003), nontarget fishing (Königson et al., 2007), structural modifications (Smith et al., 2016; Smith and Simpkins, 2017) have been investigated. However, no studies on the effect of the net material used in the equipment on fishing yield have been found.

In this study, it was aimed to compare the catch efficiency and strength of traditional fyke net rigged with two different materials knotted net and knotless net. Knotted nets have $210 \mathrm{~d} / 6$ and knotless nets have $210 \mathrm{~d} 12$ rope thickness nets which is thought to be more resistant to freshwater crab.

\section{MATERIAL AND METHOD}

The study was conducted at 3 different points of Hirfanlı Dam Lake ([39० 46' 54.58" N, 33० 46' 54.48" E], [39॰ 9' 29.52"

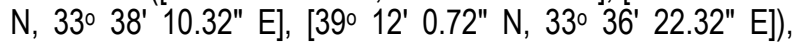
which is one of the important inland water resources of Turkey (Figure 1). The dam, which was built on the Kızılırmak River, was put into service in 1959. The maximum depth of the dam lake is reported as $69 \mathrm{~m}$ with an average lake area of 218.81 km² (DSI, 2005; Gençoğlu and Ekmekçi, 2016).

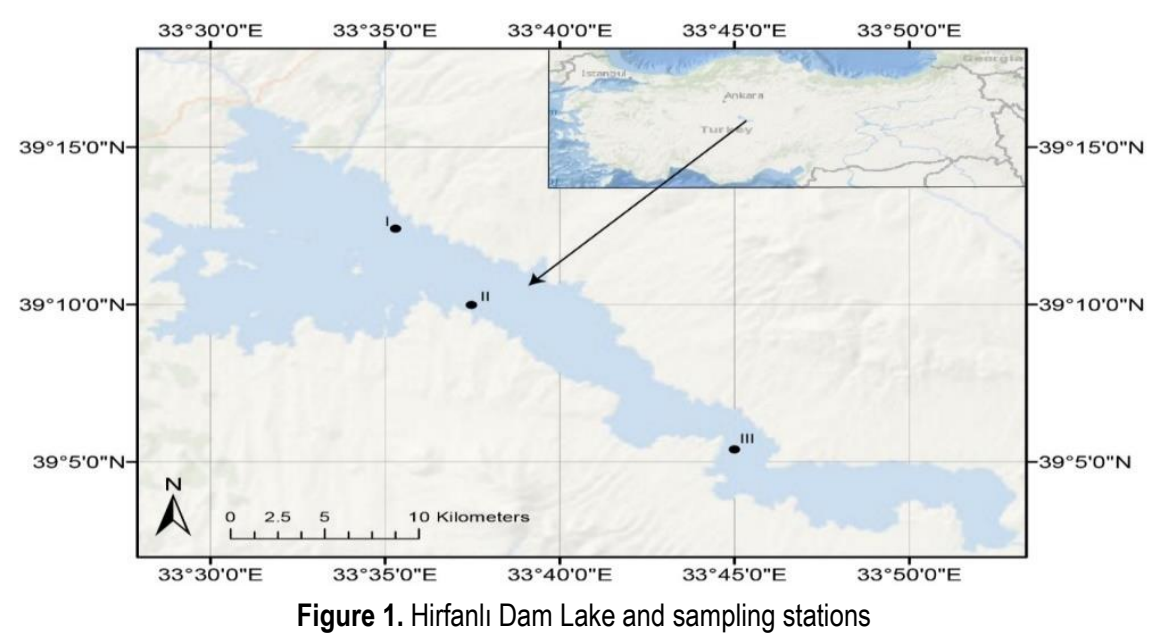




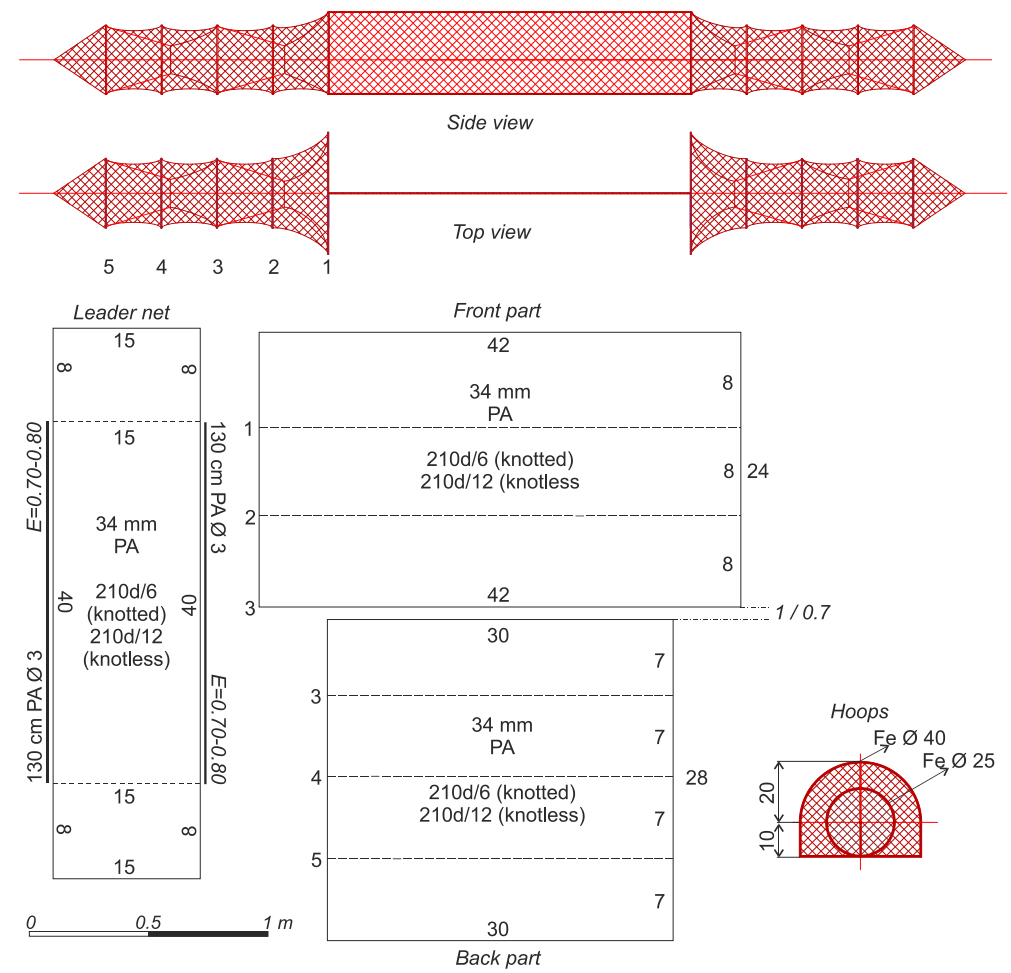

Figure 2. Technical plan of crayfish fyke net

The study was carried out on a monthly basis between June 2017 and May 2018. In fishing trials, 150 traditional crayfish fyke nets $(34 \mathrm{~mm}$ nominal stretched mesh size) rigged with 150d/6 thread-thick knotted mesh and 150 alternative crayfish fyke nets $(34 \mathrm{~mm}$ nominal stretched mesh size) rigged with $210 \mathrm{~d} / 12$ rachel knotless mesh (Figure 2) were used. In each station, 100 fyke nets, 50 of which are traditional and 50 are alternative, were used. The combined fishing gear produced with fykes connected with $1 \mathrm{~m}$ long $P A$ rope at the last bag ropes as one conventional and one alternative type, was released into water early in the morning and harvested at the same time 2 days later, as long as there were no adverse weather conditions.

The caught crayfish were classified by the fyke nets and biometric measurements (carapace and abdomen length) were performed through Mititoyo (500-181-30) brand digital caliper. With $A \& D(E J-610)$ brand digital scales, their total weight was determined at a precision of $0.01 \mathrm{~g}$. The crayfish, whose measurements were completed, were returned to the dam lake from the most suitable place while alive.

In order to determine the strength of knotless and knotted nets whose efficiency would be compared; mesh rupture resistances were measured using BURASHI brand Dyna-300 $D P$ model Handy dynamometer in 3 replicates.

CPUE values were determined according to FAO (2016) with the help of the following formulas. A fisherman and a station were taken as a basis in determining the nominal effort.

$$
\text { CPUE }=\text { total catch } / \text { nominal effort }
$$

Nominal effort (for Fyke Net) = number of traps $/$ fishing days

In the comparison of catch-per-unit-effort efficiency (CPUE) of the fyke nets tested as traditional and alternative with catch compositions and rupture resistance of knotted and knotless net, $t$-test was used, while in comparing the sample number in terms of fishing period and fyke net, the chi-square test was employed. Appropriate regression models were used to explain the relationships between variables. In all statistical calculations, $R$ (v3.6.1) based Rstudio (v1.2.5001) program was used.

\section{RESULTS}

The data obtained from the sampling of June, July and August months were not taken into consideration due to reasons such as lack of suitable stations, difficulties in the classification of the catch, low catch yield etc. As a result of fishing trials, a total of 3509 crayfish were caught, 1465 of which were caught with fyke net rigged with knotless mesh and 2044 of which were caught with fyke net rigged with knotted mesh. The total length distribution of the catch according to the sampling period and fyke net type is given in Table 1. The average length of the catch which were caught with fyke net equipped with knotless mesh was found to be lower than that of the catch caught with fyke net equipped with knotted mesh $(p<0.05)$. March $(28.5 \%)$ was the most 
productive month, while September $(3.5 \%)$ was the most unproductive month. The distribution of the catch in terms of fishing period and fyke net type was found to be statistically different $\left(X^{2}: 133.70 ; p<0.001\right)$.

During the research fishing, 19 successful operations were carried out to compare the fishing efficiencies of fyke nets rigged with knotted and knotless mesh. The CPUE values obtained ranged from 10.93 (g/fyke net/day) to 281.14 (g/fyke net/day) (Table 2).

Although the mean CPUE value calculated for knotless nets as 79.46 ( $\mathrm{g} /$ fyke net/day) was determined to be lower in comparison to the value of the fyke net rigged with knotted mesh which was calculated as 98.34 (g/fyke net/day) (Figure $3-A)$, the difference between the CPUE values was found to be statistically insignificant ( $p>0.05)$.

Mean CPUE values of trial nets according to sampling period are presented in Figure 4. In all other samples except
January samples, the fyke net rigged with knotted net was found to be more efficient compared to the alternative one. Although significant fluctuations in monthly CPUE values are observed, it is seen that there is an upward trend from autumn to summer (Figure 4).

Correlations between sampling period and CPUE of trial nets were found to be weak, Pearson correlation coefficient was computed as 0.558 and 0.587 for knotless and knotted mesh respectively. CPUE values were shown increasing by sampling period for trial fyke nets with knotless and knotted mesh (Figure 5).

Among the nets used in the rigging of fyke nets used in the trial, the mean strength value of the $210 \mathrm{~d} / 6$ knotted net was determined to be $( \pm S E) 10.43 \pm 0.27 \mathrm{~kg}$, while it was determined as $14.50 \pm 0.91 \mathrm{~kg}$ for $210 \mathrm{~d} / 12$ knotless net (Figure 3-B). The difference between the mean strength value was statistically significant $(p<0.05)$.

Table 1. Catch total length distribution by trial fyke nets $(\mathrm{mm})$

\begin{tabular}{|c|c|c|c|c|c|c|c|}
\hline \multirow{3}{*}{ Sampling period } & \multicolumn{7}{|c|}{ Type of fyke net mesh } \\
\hline & \multicolumn{3}{|c|}{ Knotless } & \multicolumn{4}{|c|}{ Knotted } \\
\hline & $N$ & Mean士SE & Min.-Max. & $N$ & Mean $\pm S E$ & Min.-Max & $p$ \\
\hline Sep-2017 & 46 & $99.12 \pm 2.45$ & $64.07-142.66$ & 78 & $100.04 \pm 1.35$ & $63.56-126.18$ & 0.723 \\
\hline Oct-2017 & 50 & $94.43 \pm 2.99$ & $58.54-131.61$ & 82 & $99.77 \pm 2.09$ & $56.29-136.96$ & 0.135 \\
\hline Nov-2017 & 158 & $93.15 \pm 1.65$ & $54.56-138.98$ & 157 & $96.62 \pm 1.55$ & $52.18-138.08$ & 0.127 \\
\hline Dec-2017 & 237 & $92.48 \pm 1.10$ & $63.24-148.30$ & 202 & $96.79 \pm 1.06$ & $60.40-135.22$ & 0.005 \\
\hline Jan-2018 & 128 & $97.66 \pm 1.79$ & $48.78-143.92$ & 116 & $99.22 \pm 1.84$ & 42.63-153.39 & 0.005 \\
\hline Feb-2018 & 68 & $99.86 \pm 1.89$ & $65.78-129.57$ & 74 & $103.98 \pm 1.56$ & $72.18-131.74$ & 0.092 \\
\hline Mar-2018 & 282 & $94.13 \pm 1.14$ & $45.04-133.10$ & 717 & $92.79 \pm 0.70$ & $51.54-142.79$ & 0.312 \\
\hline Apr-2018 & 310 & $90.06 \pm 1.17$ & $41.50-143.35$ & 418 & $93.88 \pm 1.03$ & $39.34-143.68$ & 0.015 \\
\hline May-2018 & 186 & $86.09 \pm 1.35$ & $44.29-136.47$ & 200 & $94.58 \pm 1.41$ & $56.96-138.44$ & 0.000 \\
\hline Total & 1465 & $92.62 \pm 0.51$ & $41.50-148.30$ & 2044 & $95.20 \pm 0.42$ & $39.34-153.39$ & 0.000 \\
\hline
\end{tabular}

Table 2. CPUE of trial fyke nets by sampling period ( $g /$ fyke net/ day)

\begin{tabular}{lrrrrrr}
\hline & \multicolumn{3}{c}{ Type of fyke net mesh } \\
\cline { 2 - 7 } Sampling period & \multicolumn{3}{c}{ Knotless } & \multicolumn{3}{c}{ Knotted } \\
\cline { 2 - 7 } & $16.55 \pm 2.81$ & 10.93 & 19.60 & $28.73 \pm 6.99$ & 16.88 & 41.08 \\
\cline { 2 - 7 } September-2017 & $28.31 \pm 1.32$ & 26.98 & 29.63 & $51.17 \pm 18.08$ & 33.09 & 69.25 \\
October-2017 & $89.19 \pm 14.50$ & 74.69 & 103.69 & $95.94 \pm 41.89$ & 54.05 & 137.82 \\
November-2017 & $124.23 \pm 14.14$ & 110.10 & 138.37 & $118.74 \pm 5.95$ & 112.80 & 124.69 \\
December-2017 & $75.66 \pm 58.14$ & 17.52 & 133.79 & $71.09 \pm 55.94$ & 15.15 & 127.03 \\
January-2018 & $41.19 \pm 2.04$ & 39.15 & 43.23 & $50.22 \pm 4.37$ & 45.85 & 54.59 \\
February-2018 & $149.43 \pm 23.54$ & 125.89 & 172.97 & $169.81 \pm 40.35$ & 129.45 & 210.16 \\
March-2018 & $147.02 \pm 12.91$ & 134.11 & 159.92 & $227.31 \pm 53.83$ & 173.47 & 281.14 \\
April-2018 & $75.00 \pm 28.83$ & 46.16 & 103.83 & $106.82 \pm 58.47$ & 48.34 & 165.29 \\
May-2018 & $79.46 \pm 12.56$ & 10.93 & 172.97 & $98.34 \pm 16.78$ & 15.15 & 281.14 \\
\hline Total & & & & & & Minimum \\
\hline
\end{tabular}



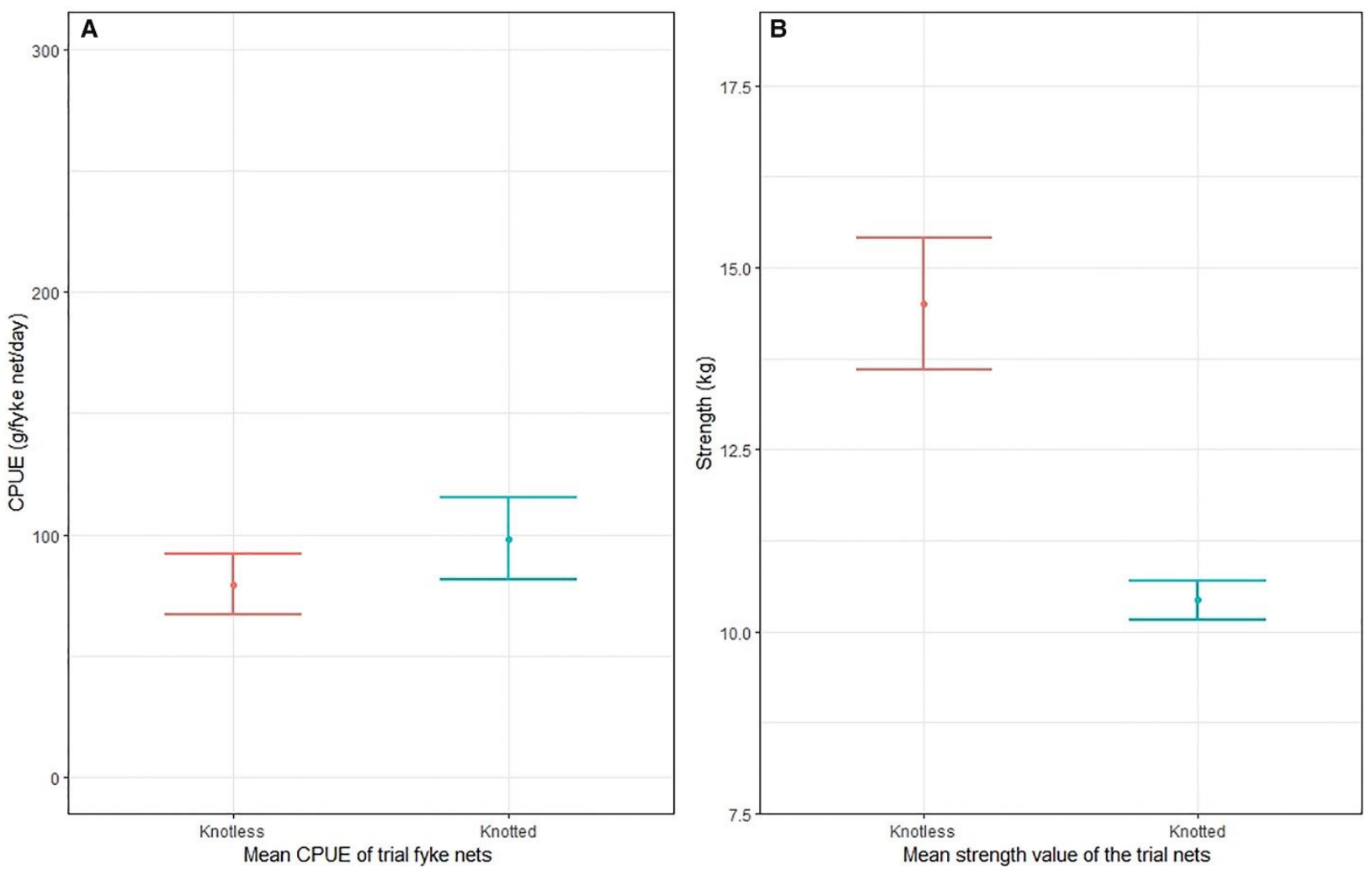

Figure 3. Mean $C P U E(A)$ and strength value $(B)$ of the trial nets

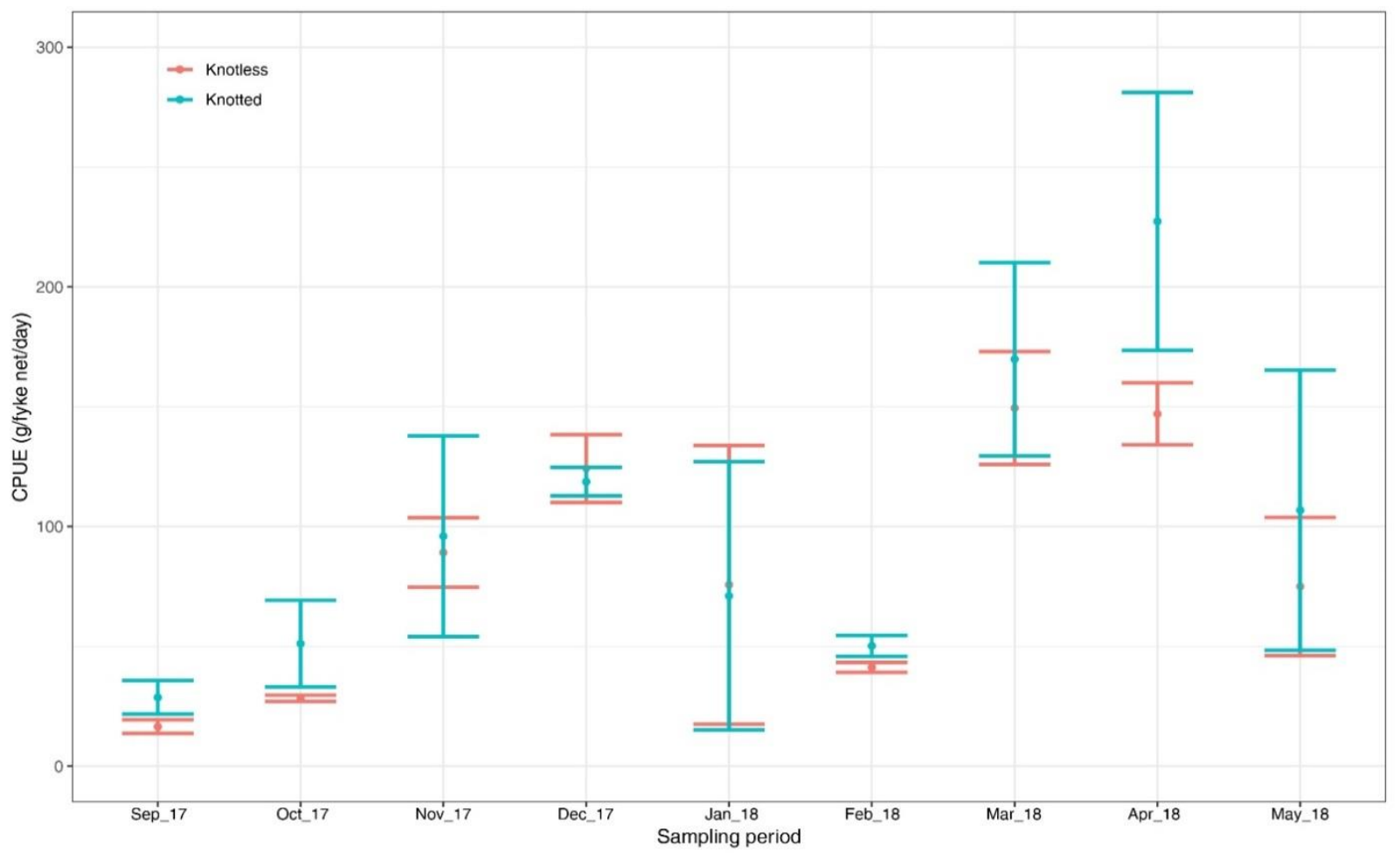

Figure 4. Monthly mean CPUE values of trial fyke nets 


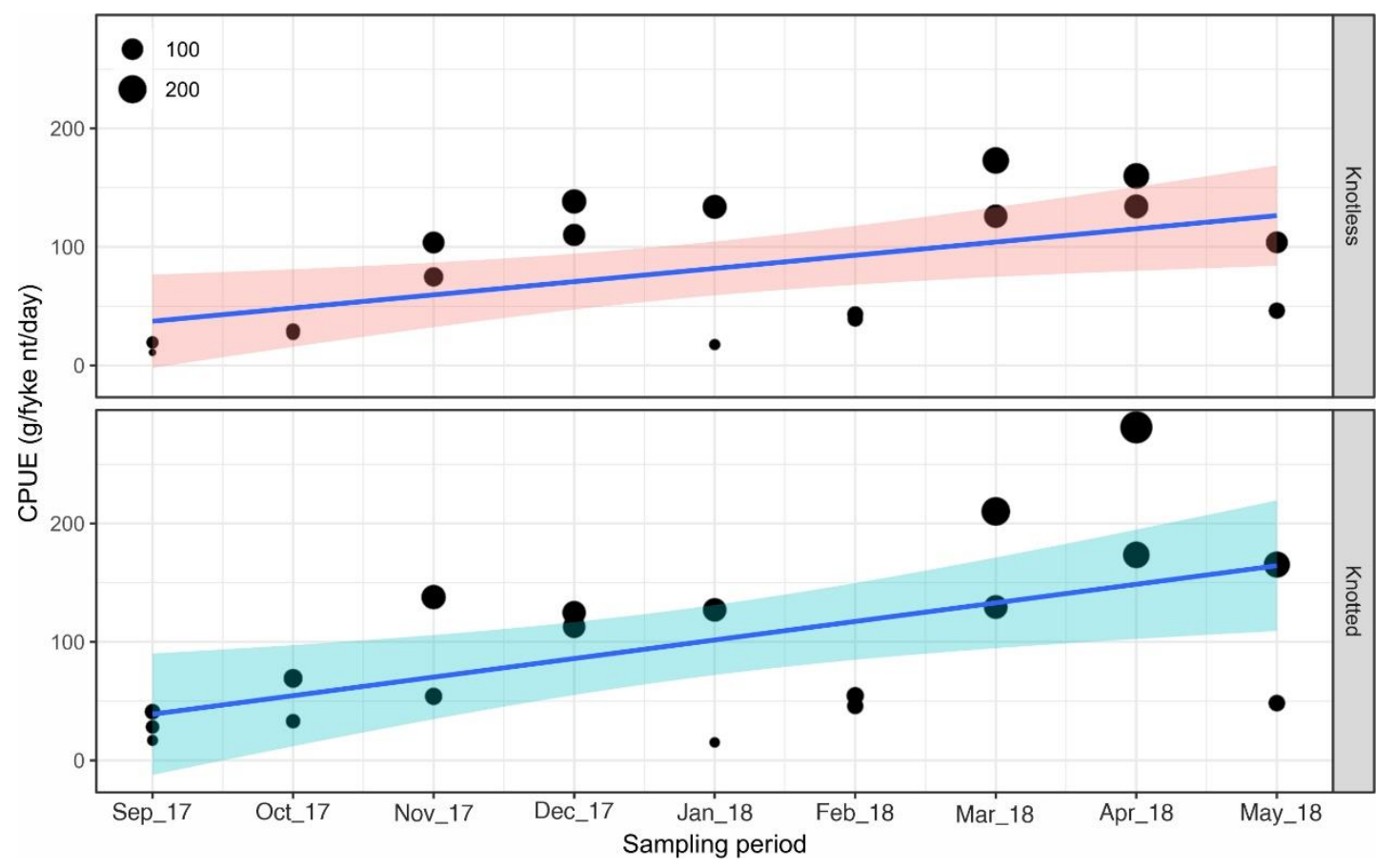

Figure 5. Relationship of sampling period and CPUE

\section{DISCUSSION}

In our study, which was carried out to investigate the effect of the net material used in rigging on the catch yield, a total of 3509 crayfish were caught, 1465 of which were caught in knotless and 2044 in knotted fyke nets. Although it is not statistically significant, it was determined that catch yield of fyke nets rigged with traditional net material is higher than that of the one rigged with alternative net material. This situation is reflected directly on CPUE values, and the CPUE value of the fyke net rigged with knotless net was 79.46 , while it was found as 98.34 for the one rigged with knotted net $(p>0.05)$. Although it is statistically insignificant, the CPUE value of the net used in the experiment as an alternative was found to be lower by approximately $19.20 \%$ than the classical net. Another report was issued by Turunen (1996) for pikeperch fish regarding the decrease in the catch yield resulting from the increase in the rope thickness. Among all the gillnets with $30,35,40-, 45-, 50-$ and 55-mm mesh gaps produced from monofilament material with $0.15-$ and $2.0-\mathrm{mm}$ rope thickness, gillnets with $0.15 \mathrm{~mm}$ rope thickness yielded more catch than gillnets with $0.20 \mathrm{~mm}$ rope thickness. In another study carried out by Grati et al. (2015) on the common sole fish in the Mediterranean, it was determined that the productivity of the nets produced from $0.18,0.20,0.22,0.25$ - and $0.30-\mathrm{mm}$ diameter monofilament material decreased due to the increase in the rope thickness. In another research conducted by Kim et al. (2016) in southwestern Sea of Korea on Larimichthys polyactis species, similar findings were obtained, and the sample numbers taken from $0.279,0.321$ - and 0.360 $\mathrm{mm}$ diameter monofilament nets were reported as 1250, 967 and 483 , respectively. In a study conducted by Broadhurst et al. (2015) on Australian recreational hoop nets, it was reported that the increase in rope thickness led to a decrease in blue swimmer crabs (Portunus pelagicus) fishing in terms of total CPUE value.

Generally, nets with thin ropes are considered more productive compared to the ones with thick ropes as they are less visible, easier to stretch and more flexible (Grati et al, 2015; Hamley, 1975, Jensen, 1995; Turunen, 1996); accordingly, the findings of our study are similar to those of other studies. Our study has demonstrated that the same situation applies to the fyke nets used in crayfish fishing.

The average size of the catch obtained from the fyke net rigged with knotless net $(92.62 \mathrm{~mm}$ ) was found to be lower than that of the catch caught with the fyke net rigged with classical net $(95.20 \mathrm{~mm})(p<0.05$; Table 2). As the inner area of mesh gap in alternative fyke net with more rope thickness is narrower, it might have allowed less small size fish to exit compared to classical net.

The general opinion among fishermen is that the thickness of rope in the net cause more biofouling material on it over time and will, therefore, decrease catch yield due to its increased visibility in water. The findings we obtained in our study support this idea (Figure 5). While, in traditional fyke net, the CPUE value was in an upward trend during the sampling period, in the alternative net fyke we experimented on, following a quick initial rise, CPUE value followed a more stable course.

Reducing the depreciation expenses in the fishing sector, as in every sector, contributes to the profitability of the 
business. In this context, the longevity of fishing gear, which is one of the most important variable expenses of fishing establishments, will contribute to the reduction of operating costs and thus increase of profitability in fishing activity. In this context, the CPUE values of alternative fyke net $(210 \mathrm{~d} / 12$ knotless), which was thought to be more durable, and the classical fyke net (210d / 6 knotted) were compared in our study. Although it has high strength, the alternative fyke net had lower CPUE value than the classical fyke net by $19.20 \%$, which was an important handicap. In this context, it is thought

\section{REFERENCES}

Ayaz, A., Acarli, D., Altinagac, U., Ozekinci, U., Kara, A. \& Ozen, O. (2006). Ghost fishing by monofilament and multifilament gillnets in Izmir Bay, Turkey. Fisheries Research, 79(3), 267-271. DOI:10.1016/j.fishres.2006.03.029

Balık, I., Çubuk, H. \& Uysal, R. (2003). Effect of Bait on Efficiency of Fykenets for Catching Crayfish Astacus leptodactylus Esch. 1823. Turkish Journal of Fisheries and Aquatic Sciences, 3(1), 1-4.

Bevacqua, D., De Leo, G. A., Gatto, M. \& Melià, P. (2009). Size selectivity of fyke nets for European eel Anguilla anguilla. Journal of Fish Biology, 74(9), 2178-2186. DOI:10.1111/j.1095-8649.2009.02243.x

Bolat, Y., Demirci, A. \& Mazlum, Y. (2010). Size Selectivity of Traps (FykeNets) of Different Mesh Size on The Narrow-Clawed Crayfish, Astacus leptodactylus (ESCHSCHOLTZ, 1823) (Decapoda, Astacidae) İn Eğirdir Lake, Turkey. Crustaceana, 8(11), 1349-1361. DOI:10.1163/001121610X536969

Bolat, Y. \& Uçgun, E. (2019). Effects of Hexagonal-and Diamond-shaped Mesh Traps on Size Selectivity of Freshwater Crayfish Astacus leptodactylus Eschscholtz, 1823 (Decapoda: Astacidae) in the Eğirdir Lake, Turkey. Acta Zoologica Bulgarica, 12(2), 1-11

Broadhurst, M. K., Butcher, P. A., Cullis, B. R. \& Tolhurst, D. J. (2015). Influences of twine diameter and mesh area on the efficiency and durability of baited hoop nets targeting portunids. 22(6), 488-500. DOI:10.1111/fme.12146

Cilbiz, M. (2019). Improving Crayfish (Astacus leptodactylus Eschscholtz, 1823) Fyke Net Selectivity [in Turkish]. (PhD), Ege Üniversitesi, Fen Bilimleri Enstitüsü, 128p.

DSI (2005). Hirfanlı ve Kesikköprü Baraj Gölleri ve Havzalarında Kirlilik Araştırması. Ankara, Turkey: General Directorate of State Hydraulic Works (in Turkish), 354p.

FAO. (2016). GFCM Data Collection Reference Framework (DCRF) v.2016.2. Retrieved from: http://www.fao.org/fileadmin/user_upload/faoweb/

Fische, J. R., Johnson, N. P., Schultz, R. D. \& Quist, M. C. (2010). A Comparison of Modified Fyke Nets for Evaluating Fish Assemblages and Population Structure. Journal of Freshwater Ecology, 25(4), 555-563. DOI:10.1080/02705060.2010.9664405

Fujimoto, Y., Hoshi, M. \& Jinguji, H. (2017). Examination of an effective trap to control North American invasive freshwater crayfish (Procambarus clari)in Japan. Ecology and Civil Engineering, 20(1), 1-10. DOI: $10.3825 /$ ece. 20.1

Geldiay, R. \& Kocataş, A. (1977). An investigation on the local population of the freshwater crabs (Potamon, Saving, 1816) in Turkey and a revision of its taxonomy. EÜ Fen Fakültesi Dergisi, Seri B, 1, 2-9

Gençoğlu, L. \& Ekmekçi, F.G. (2016). Growth and reproduction of a marine fish, Atherina boyeri (Risso 1810), in a freshwater ecosystem. Turkish Journal of Zoology, 40(4), 534-542.

Grati, F., Bolognini, L., Domenichetti, F., Fabi, G., Polidori, P., Santelli, A., Scarcella, G. \& Spagnolo, A. (2015). The effect of monofilament thickness on the catches of gillnets for common sole in the Mediterranean small-scale fishery. Fisheries Research, 164, 170-177. DOI:10.1016/j.fishres.2014.11.014 that its use in crayfish fishing will not be profitable. In future studies on the subject, fyke nets rigged with monofilament or multi-monofilament material can be examined.

\section{ACKNOWLEDGEMENT}

This study was supported by Republic of Turkey, Ministry of Agriculture and Forest, General Directorate of Agricultural Research and Policies [grant number: TAGEM/HAYSUD/2017/A11/P-02/1]. Also, authors want to thank Ege Balık Ağları Ltd.Şti. for helped of mesh breaking resistance determination.

Green, N., Bentley, M., Stebbing, P., Andreou, D. \& Britton, R. (2018). Trapping for invasive crayfish: comparisons of efficacy and selectivity of baited traps versus novel artificial refuge traps. Knowledge \& Management of Aquatic Ecosystems (419), 211-220.

DOI: $10.1051 / \mathrm{kmae} / 2018007$

Gülle, P., Tura, İ. \& Gülle, İ. (2007). Egirdir Gölü Tatlısu Yengeci (Potamon potamios Olivier. 1804)'nin Bazı Üreme ve Popülasyon Özellikleri. Süleyman Demirel Üniversitesi Fen Bilimleri Enstitüsü Dergisi, 11(2), 134-139.

Hamley, J.M. (1975). Review of gillnet selectivity. Journal of Fisheries. Board. Canada, 32, 1943-1969. DOI:10.1139/cjfas-2013-0401

Hardie, S.A., Barmuta, L.A. \& White, R.W.G. (2005). Spawning related seasonal variation in fyke net catches of golden galaxias (Galaxias auratus): implications for monitoring lacustrine galaxiid populations. Fisheries Management and Ecology, 12(6), 407-409. DOI:10.1111/j.1365-2400.2005.00454.x

Jensen, J.W. (1995). A direct estimate of gillnet selectivity for brown trout. Journal of Fish Biology, 46(5), 857-861. DOI:10.1111/j.1095-8649.1995.tb01608.x

Kim, S., Lim, J., Lee, K. \& Park, S. (2016). Effect of twine thickness on sizeselectivity of driftnet for the yellow croaker Larimichthys polyactis in southwestern Sea of Korea. Chinese Journal of Oceanology and Limnology, 34(6), 1199-1208. DOI:10.1007/s00343-016-5107-0

Königson, S., Hemmingsson, M., Lunneryd, S.-G. \& Lundström, K. (2007). Seals and fyke nets: An investigation of the problem and its possible solution. Marine Biology Research, 3(1), 29-36. DOI:10.1080/17451000601072596

Kraft, C. E. \& Johnson, B. L. (1992). Fyke-Net and Gill-Net Size Selectivities for Yellow Perch in Green Bay, Lake Michigan. North American Journal of Fisheries Management, 12(1), 230-236.

DOI:10.1577/1548-8675(1992)012<0230:FNAGNS>2.3.CO;2

Pauly, D., Christensen, V., Guénette, S., Pitcher, T.J., Sumaila, U.R., Walters, C.J.,watson, R. \& Zeller, D. (2002). Towards sustainability in world fisheries. Nature, 418(8), 689-695.

RStudio Team (2015). RStudio: Integrated Development for R. RStudio, Inc., Boston, MA URL http://www.rstudio.com/.

Smith, B.J., Blackwell, B.G., Wuellner, M.R., Graeb, B.D.S. \& Willis, D.W. (2016). Escapement of Fishes from Modified Fyke Nets with Differing Throat Configurations. North American Journal of Fisheries Management, 36(1), 96-103. DOI:10.1080/02755947.2015.1111278

Smith, B.J. \& Simpkins, D.G. (2017). A Comparison of Three Paired Modified Fyke Nets for Characterizing Fish Assemblages in the Nearshore Zone of Lake Michigan. North American Journal of Fisheries Management, 37(5), 962-969. DOI:10.1080/02755947.2017.1336134

Tokaç, A. (2011). Ağ Yapım ve Donam Tekniği (Balıkçılık II), Yayın No:80: Ege Üniversitesi Basım Evi, Bornova-İzmir, $321 \mathrm{p}$.

Tosunoğlu, Z., Ünal, V. \& Kaykaç, M.H. (2017). Ege Dalyanları. SÜR-KOOP Su Ürünleri Kooperatifleri Merkez Birliği Yayınları No: 03, Ankara, 322p. 
Tsai, C.H., Wang, Y.K., Tsai, S.T. \& Wu, S.H. (2015). Seasonal and diel changes of the fish assemblage employing the fyke nets in a subtropical mangrove estuary of puzih river, Taiwan. Journal of Marine Science and Technology, 23(1), 109-116. DOl:10.6119/JMST-014-0110-3

Turunen, T. (1996). The effects of twine thickness on the catchability of gillnets for pikeperch (Stizostedion lucioperca (L.)). Annales Zoologici
Fennici, 33(3/4), 621-625. Retrieved from www.jstor.org/stable/23736107

Ulikowski, D., Chybowski, Ł., Traczuk, P., Ulikowska, E.J.T.J.o.F. \& Sciences, A. (2017). A New Design of Crayfish Traps Reduces Escaping and Improves Opportunities for Long-Term Catching. 17(2), 363-369. 